\title{
The effects of grass and concentrate diets on the specific activities of some enzymes of hepatic carbohydrate metabolism in sheep
}

\author{
BY J. PEARCE AND E. F. UNSWORTH \\ Department of Agricultural and Food Chemistry, \\ The Queen's University of Belfast, Newforge Lane, \\ Belfast $B T_{9}{ }_{5} P X$, and Department of Agriculture, Northern Ireland \\ (Received 3 November 1975 - Accepted 17 November 1975)
}

\begin{abstract}
Feeding sheep a concentrate diet compared with grass diets increased the hepatic specific activities of the three glycolytic enzymes studied, and that of glucose-6-phosphate dehydrogenase ( $E C$ I I I I . 49), and reduced the specific activity of D-fructose-I,6-diphosphate I-phosphohydrolase $\left(E C C_{3} \cdot x_{3} \cdot \mathrm{II}\right)$. The specific activities of phosphogluconate dehydrogenase ( $E C$ I. I. I.43) and malate dehydrogenase (decarboxylating) (NADP) (EC I I.I.40) were unaffected by diet.
\end{abstract}

In contrast to the situation in simple-stomached species, where there is a large amount of literature on the effects of dietary manipulation on hepatic enzyme activity, there is relatively little information on the effects of diet on liver metabolism in ruminant animals.

The present experiment was done to study the activities of some enzymes of hepatic carbohydrate metabolism in sheep given diets known to produce wide variations in the molar proportions of volatile fatty acids (VFA) produced in the rumen.

\section{MATERIALS AND METHODS}

Three groups of six cross-bred 18 -month-old wether sheep were maintained on each of three dietary treatments for a 7 -week period before liver biopsy, and rumen and blood sampling. The treatments were a pelleted concentrate ration $((\mathrm{g} / \mathrm{kg}) 500$ barley, 200 maize, 200 soya-bean meal, 50 skim-milk powder, 50 fish meal, plus vitamins and minerals), dried-grass nuts and the grazing of a predominantly ryegrass sward. Food and water were continuously available to all animals. The animals receiving the concentrate and the dried-grass treatments were housed; the third group grazed continuously.

Liver biopsies were done in the standing animal using a technique which was essentially that of Loosemore \& Alcroft (1951). Blood samples were obtained immediately after biopsy. Rumen fluid samples were obtained $24 \mathrm{~h}$ after biopsy, using the technique described by Raun \& Burroughs (1962). The $\mathrm{pH}$ of the rumen fluid sample was measured immediately after collection. VFA in the rumen fluid were estimated by gas-liquid chromatography, using a $1.8 \mathrm{~m} \times 0.6 \mathrm{~mm}$ column containing I $50 \mathrm{~g}$ diethylene glycol sebacate/kg Chromosorb W (acid-washed) (Phase Separations 
Ltd, Queensferry, Clwyd) in a Model $\mathrm{F}_{3} \mathrm{O}$ chromatograph (Perkin-Elmer Ltd, Beaconsfield, Bucks.) at $150^{\circ}$, with 2-methyl valeric acid as an internal standard.

The liver biopsy samples (approximately $0.5 \mathrm{~g}$ ) were homogenized in 9 vol. ice-cold $0.25 \mathrm{M}$-sucrose containing $0.02 \mathrm{M}$-Tris- $\mathrm{HCl}$ buffer, $\mathrm{pH} 7.5$, and I mM-dithiothreitol. The homogenates were centrifuged at $100000 \mathrm{~g}$ for $30 \mathrm{~min}$ at $0-5^{\circ}$ (MSE Superspeed $5^{\circ}$; Measuring and Scientific Equipment Ltd, Crawley, Sussex) and the resulting cell-free extracts were assayed for the following enzyme activities. Phosphofructokinase (EC 2.7.I.II), fructosediphosphate aldolase (EC 4.1.2.13), pyruvate kinase (EC 2.7.1.40), glucose-6-phosphate dehydrogenase (EC I.I.1.49) and phosphogluconate dehydrogenase (EC I.1.1.43) were assayed as described by Pearce \& Carr (1969), D-fructose-I,6-diphosphate I-phosphohydrolase (EC 3.I.3.II) was determined using the method of Racker \& Schroeder (1958) and malate dehydrogenase (decarboxylating) (NADP) (EC I. I. I.40) as described by Pearce (1970).

The assays were done at $37^{\circ}$ using either a Model SP 8000 recording spectrophotometer (Pye Unicam Ltd, Cambridge) or a Model $300 \mathrm{~N}$ spectrophotometer (Gilford Instruments Ltd, Teddington, Middx.). In all instances the enzyme activity obtained was linear with respect to both time and the protein content of the extracts. The protein content of the extracts was determined as described by Pearce \& Carr (1969).

The results were assessed statistically by analysis of variance.

\section{RESULTS}

The results in Table $\mathrm{r}$ indicate the effects of feeding either grass, dried-grass nuts or a concentrate diet on rumen $\mathrm{pH}$, rumen VFA concentrations and blood glucose content. The mean rumen $\mathrm{pH}$ values of the sheep on the three diets were significantly different $(P<0.001)$ from each other, with the lowest $\mathrm{pH}$ associated with the concentrate diet and the highest with the fresh grass. The values for VFA content of the rumen fluid indicated that there was significantly $(P<0.00 \mathrm{I})$ more acetic acid, and significantly $(P<0.001)$ less propionic acid in the rumen fluid of the sheep given either grass or dried-grass nuts than in those receiving the concentrate diet. The acetic and propionic acid contents of the rumen fluid from sheep given either dried-grass nuts or fresh grass were also significantly different $(P<0 \circ \mathrm{Or})$. The molar proportion of isovaleric acid was significantly $(P<0.001)$ higher in the grass-fed animals and that of valeric acid was significantly $(P<0.001)$ higher in the concentrate-fed sheep. The blood glucose concentrations were similar in the sheep receiving fresh grass or concentrates and were significantly $(P<0.05)$ greater than that for sheep given dried-grass nuts.

The effects of the various diets on the specific activities of some enzymes of hepatic carbohydrate metabolism are given in Table 2. The specific activities of glucose-6phosphate dehydrogenase were similar in liver extracts from sheep given grass or dried-grass nuts but significantly greater $(P<0.01)$ in concentrate-fed animals; the specific activity of phosphogluconate dehydrogenase was similar in extracts from all three groups of sheep. The specific activities of the glycolytic enzymes, phosphofructokinase, fructosediphosphate aldolase and pyruvate kinase were not significantly 
Table I. The effects of diet on rumen $p H$, rumen volatile fatty acid (VFA) concentration and blood glucose in sheep

(Mean values for six animals/treatment)

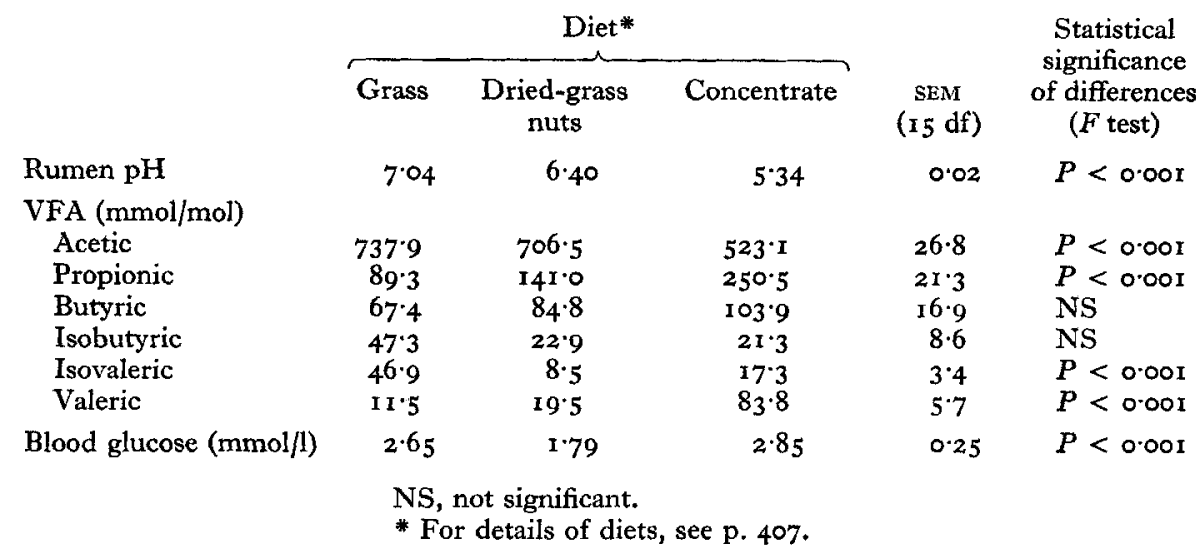

Table 2. The effects of diet on the specific activities (nmol substrate metabolized/min per mg protein in the extract) of some enzymes of hepatic carbohydrate metabolism in sheep

(Mean values for six animals/treatment)

\begin{tabular}{|c|c|c|c|c|c|}
\hline & \multicolumn{3}{|c|}{ Diet* } & \multirow[b]{2}{*}{$\begin{array}{c}\text { SEM } \\
(15 \mathrm{df})\end{array}$} & \multirow{2}{*}{$\begin{array}{c}\text { Statistical } \\
\text { significance } \\
\text { of differences } \\
(F \text { test })\end{array}$} \\
\hline & Grass & $\begin{array}{l}\text { Dried-grass } \\
\text { nuts }\end{array}$ & Concentrate & & \\
\hline $\begin{array}{l}\text { Glucose-6-phosphate } \\
\text { dehydrogenase }(E C \text { г . I . г .49 }\end{array}$ & 9) 9.06 & 10.85 & $17 \cdot 60$ & $I \cdot 32$ & $P<0.001$ \\
\hline $\begin{array}{l}\text { Phosphogluconate } \\
\text { dehydrogenase ( } E C \text { I . I . I . } 43\end{array}$ & II $5 \cdot 93$ & I 53.75 & I $37 \cdot 93$ & 13.87 & NS \\
\hline $\begin{array}{l}\text { Phosphofructokinase } \\
\qquad(E C 2 \cdot 7 \cdot \text { I.II })\end{array}$ & $47 \cdot 27$ & $3 I \cdot 80$ & $69 \cdot 56$ & 6.03 & $P<0.01$ \\
\hline $\begin{array}{l}\text { Fructosediphosphate } \\
\text { aldolase }(E C 4 \cdot 1 \cdot 2 \cdot 13)\end{array}$ & $49 \cdot \circ 3$ & 54.94 & $88 \cdot 88$ & $5 \cdot 12$ & $P<0.001$ \\
\hline $\begin{array}{l}\text { Pyruvate kinase } \\
\qquad(E C 2 \cdot 7 \cdot 1.40)\end{array}$ & 66.75 & $54 \cdot 10$ & r $55 \cdot 12$ & $I I \cdot 2 I$ & $P<0.00 \mathrm{r}$ \\
\hline $\begin{array}{l}\text { D-fructose- I,6-diphosphate } \\
\text { I-phosphohydrolase } \\
\text { (EC 3.I.3.II) }\end{array}$ & $187 \cdot 50$ & I $98 \cdot 6 \mathrm{I}$ & I 53.45 & 10.01 & $P<0.05$ \\
\hline $\begin{array}{l}\text { Malate dehydrogenase } \\
\text { (decarboxylating) (NADP) } \\
\text { (EC I.1.1.40) }\end{array}$ & 8.00 & $12 \cdot 67$ & $9 \cdot 47$ & $2 \cdot 11$ & NS \\
\hline
\end{tabular}

different in the sheep given either grass or dried-grass nuts but were significantly greater (phosphofructokinase, $P<0.05$; fructosediphosphate aldolase, pyruvate kinase, $P<0.001$ ) in liver extracts from concentrate-fed sheep. In the instance of the gluconeogenic enzyme fructose-I,6-diphosphate I-phosphohydrolase, specific activity was significantly lower $(P<0.05)$ in concentrate-fed animals than in sheep 
given either of the grass diets. The specific activities of malate dehydrogenase (decarboxylating) (NADP) were not significantly different in extracts from the three groups of animals.

\section{DISCUSSION}

The expected differences in the molar proportions of the VFA and rumen $\mathrm{pH}$, as a result of concentrate or grass feeding, were obtained.

The specific activities of the enzymes of glycolysis, and glucose-6-phosphate dehydrogenase were significantly greater in liver extracts from sheep given the concentrate diet compared with either of the grass diets. Other workers have reported that the type of diet influences enzyme activities in liver and adipose tissues. Martin, Wilson, Cowan \& Sink (1973) found that the hepatic specific activities of glucose-6phosphate dehydrogenase and phosphogluconate dehydrogenase were greater in concentrate-fed than in hay-fed sheep. Concentrate feeding also increases the specific activities of these dehydrogenase enzymes in sheep (Martin et al. 1973) and cattle adipose tissue (Opstvedt, Baldwin \& Ronning, I967; Young, Thorp \& de Lumen, 1969) compared with hay-fed animals.

The hepatic specific activity of D-fructose-I,6-diphosphate I-phosphohydrolase was studied to determine the effects of the diets on gluconeogenesis. Greater activities were found in sheep given the grass diets, which suggested that the rate of gluconeogenesis was higher in these animals than the concentrate-fed sheep.

These findings would suggest that the concentrate-fed animals obtained a greater amount of glucose directly from the diet than did the sheep given the two grass diets.

The intravenous infusion of glucose into fed sheep causes a significant increase in the incorporation of glucose into fatty acids in both liver and adipose tissues, and also significant increases in the specific activities of the lipogenic enzymes, ATP citrate lyase (EC 4.1 .3 .8$)$ and malate dehydrogenase (decarboxylating) (NADP), in these tissues (Lindsay, 1970; Ballard, Filsell \& Jarrett, 1972). Considering the possibility that glucose may be used as a carbon source for lipogenesis under conditions where glucose availability from the diet is increased, the activity of malate dehydrogenase (decarboxylating) (NADP) was studied. The enzyme activity was readily detectable but there were no significant differences in specific activity between any of the dietary treatments, suggesting that hepatic lipogenesis from glucose is not increased by concentrate feeding.

Results reviewed by Armstrong \& Beever (1969) indicate that, with diets high in barley, glucose derived from unfermented starch would make an appreciable contribution to the over-all glucose requirements of sheep. It has recently been reported that the amount of bacterial carbohydrates entering the duodenum varies according to the diet in sheep and cows (McAllan \& Smith, 1974) and a greater amount of $\alpha$-dextran is found in bacterial samples from animals given a concentrate diet compared with those given an all-roughage diet. These results indicate that a greater amount of glucose enters the duodenum of concentrate-fed ruminants, both as unfermented dietary starch and as bacterial carbohydrates, than in animals on high-roughage diets, and support the results of the present work. 
The authors thank Mr A. H. Johnson and Mr C. A. Billington for technical assistance, and $\mathrm{Mr}$ J. T. G. Hamilton for care of the animals. They also thank Dr C. H. McMurray for the blood glucose determinations.

\section{REFERENCES}

Armstrong, D. G. \& Beever, D. E. (1969). Proc. Nutr. Soc. 28, г2 1.

Ballard, F. J., Filsell, O. H. \& Jarrett, I. G. (1972). Biochem. 7 . 126, 193.

Lindsay, D. B. (1970). In Physiology of Digestion and Metabolism in the Ruminant, p. 438 [A. T. Phillipson, editor]. Newcastle upon Tyne: Oriel Press.

Loosemore, R. M. \& Alcroft, R. (195I). Vet. Rec. 63, 4 I4.

McAllan, A. B. \& Smith, R. H. (r974). Br. J. Nutr. 31, 77.

Martin, R. J., Wilson, L. L., Cowan, R. L. \& Sink, J. D. (1973). F. Anim. Sci. 36, ror.

Opstvedt, J., Baldwin, R. L. \& Ronning, M. (1967). F. Dairy Sci. 50, 108.

Pearce, J. (1970). Int. F. Biochem. r, 306.

Pearce, J. \& Carr, N. G. (1969). F. gen. Microbiol. 54, 451.

Racker, E. \& Schroeder, E. A. R. (1958). Archs Biochem. Biophys. 74, 326.

Raun, N. \& Burroughs, W. (г 962). $\mathscr{H}$. Anim. Sci. 2r, 454.

Young, J. W., Thorp, S. L. \& de Lumen, H. Z. (1969). Biochem. Y. 114, 83. 